\title{
Genetic Variability, Correlation and Path coefficient analysis for Yield and Quality traits in Okra [Abelmoschus esculentus (L.) Moench]
}

\author{
Amba Kumari ${ }^{1 *}$, Vijay Kumar Singh ${ }^{1}$, Manju Kumari ${ }^{1}$ and Anand Kumar ${ }^{2}$ \\ ${ }^{1}$ Department of Vegetable Science, Bihar Agricultural University, \\ Sabour (Bhagalpur)-813210, Bihar, India \\ ${ }^{2}$ Department of Plant Breeding \& Genetics Bihar Agricultural University, Sabour \\ (Bhagalpur)-813210, Bihar, India \\ *Corresponding author
}

\section{Keywords}

Abelmoschus esculentus L. Moench, Genetic variability,

Correlation coefficient and path analysis

Article Info

Accepted:

10 May 2019

Available Online:

10 June 2019

\section{A B S T R A C T}

The present investigation was carried out to estimate the extent of genetic variability for yield, its components and quality traits, genetic association, path coefficient analysis in thirty one hybrids of okra (Abelmoschus esculentus L. Moench). High values of phenotypic and genotypic coefficients of variation were recorded for important traits including yield per plant, number of fruits per plant and primary branches per plant respectively. High heritability were recorded yield per plant $(96.00 \%)$ followed by ascorbic acid $(75.00 \%)$, fruit width $(73.00 \%)$ and number of nodes per plant $(61.00 \%)$. Genetic advance as percent of mean ranged from 33.03 for yield per plant to 0.70 for days to $50 \%$ flowering. High genetic advance was recorded for yield per plant $(91.70 \%)$. High heritability coupled with high genetic advance was recorded for yield per plant and number of fruits per plant indicating that these characters are governed by additive gene effects and directional selection for these traits would be more effective. fruit length, fruit width, average fruit weight and number of fruits per plant and it was significantly and negatively associated with internodal length and number of nodes. Path analysis revealed that fruit width, number of nodes per plant, days to 50\% flowering and TSS had positive direct effect on yield per plant. The present study has clearly indicated the need for giving due weight age to fruit length, fruit width, average fruit weight and number of fruits per plant and number of nodes per plant for improving yield in okra. The above mention traits should be given due emphasis for future okra genetic improvement because they possess high genetic variance, heritability coupled with high genetic correlation among themselves which may yield high genetic advance under proper selection pressure in a breeding programme.

\section{Introduction}

Okra or lady's finger, (Abelmoschusesculentus L. Moench) commonly known as bhindi in India is the most popular vegetable of the family Malvaceae. It is valued for its medicinal properties to cure renal colic, leucorrhoea; chronic dysentery and goitre due to high iodine content in fruits. The dried stems of okra are used for clarification of 
sugarcane juice. Okra is categorized under often cross-pollinated group and it is an interesting crop to the breeders and geneticists for its monodelphous condition of the stamens and large flower amendable to emasculation and high number of seeds production in one pollination. The assessment of variability present in any crop species is an essential prerequite for formulating an effective breeding programme, as the existing variability can be used to enhance the yield level of cultivars following appropriate breeding strategies. The information on heritability alone may not help to identify characters for selection whereas heritability estimates in conjunction with predicted genetic advance is more reliable (Johnson et al., 1955). Heritability provides the information on the magnitude of inheritance of characters from parent to offspring, while genetic advance will be helpful in finding the actual gain expected under selection. Estimation of correlation coefficient among the yield contributing variable is necessary to understand the direction of selection and to maximize yield in the shortest period of time. Genetic correlation indicates the relative importance of character(s) on which greater emphasis should be made in selection for yield. However, as the number of variables in the correlation study increases the direct and indirect association between yield and particular component character becomes complex. It only reveals the direction and magnitude of association between any two characters but the path coefficient analysis helps in partitioning the correlation into direct and indirect effects of various yield components on yield. The success of a systematic breeding programme depends mainly on judicious selection of promising parents from the gene pool, a clear understanding of the genetic mechanism involved in combining ability, heritability, genetic advance and association of different yield attributing characters with yield, which help the breeder in deciding the appropriate breeding procedure towards the genetic potential. Hence, the present investigation was taken up to study the association of yield and its component traits in okra.

\section{Materials and Methods}

The study was conducted at the Vegetable Science Research Farm, Bihar Agricultural university, Sabour, Bhagalpur, Bihar during 2016. The experiment consisted of twenty one hybrids sown in randomized complete block design with three replications. Recommended cultural practices were followed to raise a good crop. The quantitative characters viz. plant height $(\mathrm{cm})$, number of branches per plant, days to first flowering, internodal length $(\mathrm{cm})$, number of nodes per plant, days to $50 \%$ flowering, days to first harvesting, fruit weight $(\mathrm{g})$, number fruit per plant, fruit length $(\mathrm{cm})$, fruit width $(\mathrm{cm})$, seeds per pod, yield per plant (g) The quality parameters viz., ascorbic acid, TSS (Brix) were estimated as per standard procedure. Heritability (broadsense) was estimated according to Hanson et al (1956). Phenotypic and genotypic coefficients of variation were estimated as per Burton (1952). Genetic advance as percent of mean was estimated according to Johnson et al., (1955).The phenotypic and genotypic correlation coefficient was calculated as per formulae suggested by Al-Jibouri et al., (1958) and Miller et al., (1958). The path coefficient analysis was performed according to Dewey and $\mathrm{Lu}$ (1959).

\section{Results and Discussion}

The analysis of variance revealed highly significant differences among the genotypes for all the characters except intermodal length (Table 1). This in turn indicated that there was sufficient variability present in the material studied, which could be utilized in further 
breeding programme. The estimation of genetic variability parameters for yield, its components and quality traits are presented in Table 2. The phenotypic coefficient of variation was found to be higher than the genotypic coefficient of variation for all traits under study. High values of phenotypic and genotypic coefficients of variation were recorded for important traits including yield per plant, number of fruits per plant and primary branches per plant respectively. The genotypic coefficient of variation obtained for yield and its attributing traits ranged from 0.64-16.36. Moderate genotypic coefficient of variation was observed for yield per plant (16.36) followed by number of fruits per plant (14.12) and primary branches per plant (13.39). Phenotypic coefficient of variation was high for number of fruits per plant (20.71) followed by intermodal length (16.83) and yield per plant (16.68). Higher genotypic and phenotypic coefficient of variation was recorded for number of fruits per plant and yield per plant indicated that, these test hybrids exhibited much variation among themselves with respect to these characters offering more scope for selection. These results are in agreement with the results of Singh et al., (2006), Pal et al., (2010) and Kumar and Kumar (2014). For different characters range of heritability varied from 18 to 96 per cent (Table 2). The highest heritability was shown for yield per plant (96.00\%) followed by ascorbic acid $(75.00 \%)$, fruit width $(73.00 \%)$ and number of nodes per plant $(61.00 \%)$. Genetic advance as percent of mean ranged from 33.03 for yield per plant to 0.70 for days to $50 \%$ flowering. High genetic advance was recorded for yield per plant $(91.70 \%)$. High genetic advance indicated that, additive genes govern these characters and selection will be rewarding for improvement of these traits. The genetic advance was low for days to $50 \%$ flowering, days to $1^{\text {st }}$ flowering, days to $1^{\text {st }}$ harvesting and TSS. Similar type of results were reported by Mehta et al., (2006), Saifullah et al., (2009), Pal et al., (2009), and Reddy et al., (2012) in okra. High heritability coupled with low genetic advance, low heritability with high genetic advance or low heritability and low genetic advance offers less scope for selection because of non additive genetic effects. High heritability coupled with high genetic advance showed greater proportion of additive genetic variance and consequence a high genetic gain expected from selection (Devi and Mariappan, 2013). The characters having heritability with low genetic advance as percent of mean appeared to be controlled by non-additive gene action and selection for such characters may not be effective (Singh and Singh, 2007).

Yield is the result of the expression and association of several yield attributing traits, which contribute additively or help in some conditions in modifying the expression of other traits directly or indirectly. It is therefore desirable for plant breeder to know the extent of relationship between yield and its various components, which will inevitably facilitate selection of desirable characteristics. Phenotypic correlation analysis (Table 3) revealed that yield per plant showed highly significant and positive association with fruit length, fruit width, average fruit weight and number of fruits per plant while, it showed highly significant and negative association with internodal length and number of nodes. Fruit width, fruit weight, fruit length, number of fruits per plant and number of nodes per plant is positively and significantly correlated with yield per plant while, plant height, days to $50 \%$ flowering, intermodal length, ascorbic acid and TSS were negatively and significantly correlated with yield per plant at genotypic level (Table 4). Similar finding were reported by Singh et al., (2006) and Kumar and Reddy (2016). 
Table.1 Analysis of variance for fifteen quantitative characters of twenty one hybrids of okra

\begin{tabular}{|l|c|c|c|}
\hline & \multicolumn{3}{|c|}{ Mean Sum of Square } \\
\hline Characters & $\begin{array}{c}\text { Replication } \\
(\mathbf{d f = 2})\end{array}$ & $\begin{array}{c}\text { Genotypes } \\
(\mathbf{d f = 2 9})\end{array}$ & $\begin{array}{c}\text { Error } \\
\text { (df=58) }\end{array}$ \\
\hline Plant height (cm) & 5.435 & $149.021^{* *}$ & 29.579 \\
\hline Primary branches/ plant & 0.291 & $0.3003 * *$ & 0.082 \\
\hline Days to 1st flowering & 0.097 & $1.225 * *$ & 0.392 \\
\hline Days to 50\% flowering & 0.099 & $0.475^{* *}$ & 0.217 \\
\hline Days to 1st harvest & 0.305 & $1.610^{* *}$ & 0.773 \\
\hline Internodal length (cm) & 1.217 & 4.378 & 2.639 \\
\hline Number of nodes/plant & 3.326 & $8.809 * *$ & 1.569 \\
\hline Fruit length (cm) & 0.287 & $3.3207 * *$ & 1.394 \\
\hline Fruit width (cm) & 0.0017 & $0.028 * *$ & 0.003 \\
\hline Fruit weight (g) & 3.003 & $7.330^{* *}$ & 1.895 \\
\hline Number of fruits/plant & 0.796 & $11.3001 * *$ & 3.132 \\
\hline Yield/plant (kg) & 41.387 & $6267.449 * *$ & 83.17 \\
\hline Number of seed/pod & 31.54 & $75.6200^{* *}$ & 30.451 \\
\hline Ascorbic acid (mg/100g) & 0.289 & $6.749 * *$ & 0.680 \\
\hline TSS (\%) & 0.002 & $0.069 * *$ & 0.021 \\
\hline
\end{tabular}

$*$, ** Significant at $5 \%$ and $1 \%$ levels of significance, respectively

Table.2 Estimation of genetic variability parameters for yield, its components and quality traits in okra

\begin{tabular}{|l|c|c|c|c|c|}
\hline Characters & GCV & PCV & $\mathbf{h}^{\mathbf{2}}$ & GA & GA \% of Mean \\
\hline Plant height (cm) & 6.59 & 8.71 & 0.57 & 9.85 & 10.29 \\
\hline Primary branches/ plant & 13.39 & 19.58 & 0.47 & 0.38 & 18.85 \\
\hline Days to 1st flowering & 1.53 & 2.37 & 0.41 & 0.70 & 2.02 \\
\hline Days to 50\% flowering & 0.64 & 1.20 & 0.28 & 0.32 & 0.70 \\
\hline Days to 1st harvesting & 1.24 & 2.40 & 0.26 & 0.56 & 1.31 \\
\hline Internodal length(cm) & 7.14 & 16.83 & 0.18 & 0.67 & 6.24 \\
\hline Nodes/plant & 11.61 & 14.89 & 0.61 & 2.51 & 18.66 \\
\hline Fruit length (cm) & 5.55 & 9.88 & 0.32 & 0.93 & 6.42 \\
\hline Fruit width (cm) & 5.26 & 6.14 & 0.73 & 0.16 & 9.30 \\
\hline Fruit weight(g) & 7.56 & 10.81 & 0.49 & 1.94 & 10.88 \\
\hline Number of fruits/plant & 14.12 & 20.71 & 0.47 & 2.32 & 19.84 \\
\hline Yield/plant(g) & 16.36 & 16.68 & 0.96 & 91.70 & 33.03 \\
\hline Number of seeds/pod & 6.46 & 11.22 & 0.33 & 4.60 & 7.65 \\
\hline Ascorbic Acid(mg/100g) & 10.13 & 11.71 & 0.75 & 2.53 & 18.05 \\
\hline TSS (\%) & 2.31 & 3.56 & 0.42 & 0.17 & 3.08 \\
\hline
\end{tabular}


Table.3 Phenotypic correlation coefficient between yield, its components and quality characters in twenty one hybrids of okra

\begin{tabular}{|c|c|c|c|c|c|c|c|c|c|c|c|c|c|c|}
\hline Character & PB & DFF & D50F & DFH & IL & NP & FL & FrWd & FrW & FrP & YP & SP & $\mathbf{A A}$ & TSS \\
\hline PH & -0.067 & $0.343 * *$ & 0.177 & -0.025 & 0.094 & -0.084 & -0.172 & -0.095 & -0.063 & -0.104 & -0.147 & -0.117 & $-0.208^{*}$ & 0.072 \\
\hline PB & & -0.126 & -0.178 & -0.133 & -0.001 & 0.147 & 0.019 & 0.127 & $0.238^{*}$ & 0.058 & 0.050 & 0.025 & -0.068 & -0.177 \\
\hline DFF & & & $0.261 *$ & 0.035 & 0.026 & -0.131 & $-0.249 *$ & -0.166 & $-0.295^{* *}$ & -0.152 & -0.138 & 0.009 & -0.181 & -0.139 \\
\hline D50F & & & & $-0.314 * *$ & -0.073 & -0.126 & 0.011 & -0.146 & -0.206 & -0.084 & 0.006 & -0.015 & -0.042 & $0.209 *$ \\
\hline DFH & & & & & -0.023 & -0.056 & 0.091 & 0.049 & -0.022 & -0.023 & -0.059 & 0.079 & -0.140 & 0.068 \\
\hline IL & & & & & & $-0.457 * *$ & $-0.239 *$ & $-0.489 * *$ & $-0.291 * *$ & $-0.304 * *$ & $-0.596 * *$ & $0.230 *$ & 0.185 & -0.090 \\
\hline NP & & & & & & & $0.378 * *$ & $0.690 * *$ & $0.481 * *$ & $0.481 * *$ & $0.702 * *$ & -0.160 & $-0.286^{* *}$ & 0.036 \\
\hline FL & & & & & & & & $0.604 * *$ & $0.364 * *$ & $0.512 * *$ & $0.409 * *$ & 0.075 & -0.018 & 0.000 \\
\hline FrWd & & & & & & & & & $0.596 * *$ & $0.621 * *$ & $0.709 * *$ & -0.017 & -0.174 & -0.035 \\
\hline FrW & & & & & & & & & & $0.529 * *$ & $0.415 * *$ & -0.053 & 0.079 & -0.040 \\
\hline FrP & & & & & & & & & & & $0.414 * *$ & 0.159 & -0.099 & 0.022 \\
\hline YP & & & & & & & & & & & & -0.155 & $-0.303 * *$ & 0.070 \\
\hline SP & & & & & & & & & & & & & 0.033 & -0.104 \\
\hline $\mathbf{A A}$ & & & & & & & & & & & & & & -0.104 \\
\hline & & & & & & & & & & & & & & \\
\hline
\end{tabular}

*,** Significant at $5 \%$ and $1 \%$ levels of significance, respectively

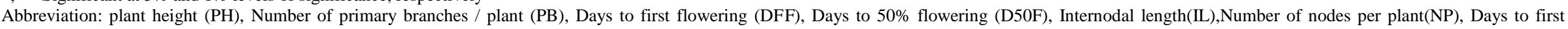

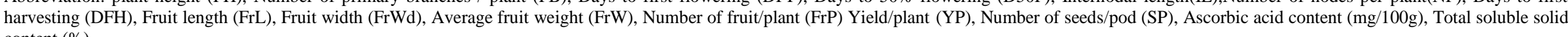
content (\%) 
Table.4 Genotypic correlation coefficient between yield and its components and quality characters in twenty one hybrids of okra

\begin{tabular}{|c|c|c|c|c|c|c|c|c|c|c|c|c|c|c|}
\hline $\begin{array}{l}\text { Characte } \\
\text { r }\end{array}$ & PB & DFF & D50F & DFH & IL & NP & FL & FrWd & FrW & FrP & SP & $\mathbf{A A}$ & TSS & $\mathbf{Y P}$ \\
\hline PH & $-0.27 * *$ & $0.542 * *$ & $0.618 * *$ & $0.303 * *$ & $0.317 * *$ & -0.14 & $-0.274 * *$ & -0.101 & -0.077 & -0.176 & $-0.27 * *$ & -0.17 & 0.17 & $-0.204 *$ \\
\hline DFF & & & $0.851 * *$ & 0.139 & $0.366^{* *}$ & $-0.233^{*}$ & $-0.364 * *$ & $-0.322 * *$ & $-0.451 * *$ & $-0.375 * *$ & $0.202^{*}$ & -0.162 & $-0.21 *$ & $-0.26^{*}$ \\
\hline D50F & & & & $-0.317 * *$ & -0.13 & -0.107 & -0.054 & -0.168 & -0.088 & -0.164 & $-0.54 * *$ & $-0.216^{*}$ & $0.383^{* *}$ & -0.041 \\
\hline DFH & & & & & 0.159 & $-0.246^{*}$ & $-0.292 * *$ & -0.068 & 0.126 & 0.1201 & $0.025^{*}$ & -0.153 & 0.133 & -0.088 \\
\hline IL & & & & & & $-0.919 * *$ & $-0.713 * *$ & $-0.349 * *$ & $-0.96^{* *}$ & $-0.932 * *$ & $0.218^{*}$ & $0.655 * *$ & $-0.45 * *$ & $-0.928 * *$ \\
\hline NP & & & & & & & $0.909^{* *}$ & $0.959^{* *}$ & $0.738^{* *}$ & $0.777^{* *}$ & $-0.39 * *$ & $-0.341 * *$ & 0.049 & $0.936^{* *}$ \\
\hline FL & & & & & & & & $0.967 * *$ & $0.921 * *$ & $0.951^{* *}$ & 0.013 & -0.136 & 0.166 & $0.741 * *$ \\
\hline FrWd & & & & & & & & & 1.032 & $0.979 * *$ & 0.068 & $-0.224 *$ & 0.042 & $0.804 * *$ \\
\hline FrW & & & & & & & & & & $0.846^{* *}$ & -0.06 & 0.097 & -0.14 & $0.646 * *$ \\
\hline FrP & & & & & & & & & & & 0.195 & -0.198 & 0.103 & $0.588 * *$ \\
\hline AA & & & & & & & & & & & & & $-0.32 * *$ & $-0.345 * *$ \\
\hline TSS & & & & & & & & & & & & & & 0.112 \\
\hline & & & & & & & & & & & & & & \\
\hline
\end{tabular}

$* * *$ Significant at $5 \%$ and $1 \%$ levels of significance, respectively

Abbreviation::plant height ( $\mathrm{PH}$ ), Number of primary branches / plant (PB), Days to first flowering (DFF), Days to 50\% flowering (D50F), Internodal length(IL),Number of nodes per plant(NP), Days to

first harvesting (DFH), Fruit length (FrL), Fruit width (FrWd), Average fruit weight (FrW), Number of fruit/plant (FrP) Yield/plant (YP), Number of seed/pod (SP), Ascorbic acid content (mg/100g),

Total soluble solid content $(\%)$ 
Table.5 Direct and indirect effect of different characters on fruit yield in okra

\begin{tabular}{|c|c|c|c|c|c|c|c|c|c|c|c|c|c|}
\hline Character & PH & PB & DFF & D50F & DFH & IL & NP & FL & FrWd & FrW & SP & $\mathbf{A A}$ & TSS \\
\hline PH & -0.141 & 0.010 & -0.049 & -0.025 & 0.004 & -0.013 & 0.012 & 0.024 & 0.013 & 0.009 & 0.017 & 0.029 & -0.010 \\
\hline PB & 0.002 & -0.029 & 0.004 & 0.005 & 0.004 & 0.000 & -0.004 & -0.001 & -0.004 & -0.007 & -0.001 & 0.002 & 0.005 \\
\hline DFF & 0.001 & -0.001 & 0.004 & 0.001 & 0.000 & 0.000 & -0.001 & -0.001 & -0.001 & -0.001 & 0.000 & -0.001 & -0.001 \\
\hline D50F & 0.015 & -0.015 & 0.021 & 0.082 & -0.026 & -0.006 & -0.010 & 0.001 & -0.012 & -0.017 & -0.001 & -0.003 & 0.017 \\
\hline DFH & 0.003 & 0.013 & -0.004 & 0.032 & -0.101 & 0.002 & 0.006 & -0.009 & -0.005 & 0.002 & -0.008 & 0.014 & -0.007 \\
\hline IL & -0.021 & 0.000 & -0.006 & 0.017 & 0.005 & -0.229 & 0.105 & 0.055 & 0.112 & 0.067 & -0.053 & -0.042 & 0.021 \\
\hline NP & -0.024 & 0.042 & -0.038 & -0.036 & -0.016 & -0.132 & 0.288 & 0.109 & 0.199 & 0.138 & -0.046 & -0.082 & 0.010 \\
\hline FL & -0.003 & 0.000 & -0.004 & 0.000 & 0.002 & -0.004 & 0.006 & 0.017 & 0.010 & 0.006 & 0.001 & 0.000 & 0.000 \\
\hline FrWd & -0.040 & 0.053 & -0.069 & -0.061 & 0.020 & -0.203 & 0.287 & 0.251 & 0.416 & 0.248 & -0.007 & -0.072 & -0.015 \\
\hline FrW & 0.000 & -0.002 & 0.002 & 0.002 & 0.000 & 0.002 & -0.004 & -0.003 & -0.005 & -0.008 & 0.000 & -0.001 & 0.000 \\
\hline SP & 0.003 & -0.001 & 0.000 & 0.000 & -0.002 & -0.006 & 0.004 & -0.002 & 0.000 & 0.001 & -0.026 & -0.001 & 0.003 \\
\hline $\mathbf{A A}$ & 0.027 & 0.009 & 0.023 & 0.005 & 0.018 & -0.024 & 0.037 & 0.002 & 0.022 & -0.010 & -0.004 & -0.128 & 0.013 \\
\hline TSS & 0.002 & -0.005 & -0.004 & 0.005 & 0.002 & -0.002 & 0.001 & 0.000 & -0.001 & -0.001 & -0.003 & -0.003 & 0.026 \\
\hline $\begin{array}{l}\text { Phenotypic } \\
\text { correlation with YP }\end{array}$ & -0.147 & 0.050 & -0.138 & 0.006 & -0.059 & -0.596 & 0.702 & 0.409 & 0.709 & 0.415 & -0.155 & -0.303 & 0.070 \\
\hline
\end{tabular}

$*$, ** Significant at $5 \%$ and $1 \%$ levels of significance, respectively. Residual effect $=0.555$

Abbreviation: Plant height (PH), Number of primary branches / plant (PB), Days to first flowering (DFF), Days to 50\% flowering (D50F), Internodal length(IL),Number of nodes per plant(NP), Days to first harvesting (DFH), Fruit length (FrL), Fruit width (FrWd), Average fruit weight (FrW), Number of fruit/plant (FrP) Yield/plant (YP), Number of seeds/pod (SP), Ascorbic acid content (mg/100g), Total soluble solid content (\%) 
Path coefficient analysis provides an effective means of partitioning correlation coefficients into unidirectional and alternative pathways thus permitting a critical examination of specific factors that produce a given correlation, which can be successfully employed in formulating an effective selection programme. Path analysis (Table 5) revealed that fruit width, number of nodes per plant, days to $50 \%$ flowering, days to first flowering, fruit length, and TSS had positive direct effect on fruit yield. The result is in close conformity with that Mehta et al., (2006), Akinyele and Osekita (2006), Solankey and Singh (2009) and Kumar and Reddy (2012) in okra. From the present study it can be inferred that the characters viz. fruit width, number of nodes per plant, days to $50 \%$ flowering, days to first flowering, fruit length, and TSS showed positive direct effect on yield Therefore these characters should be considered for selection to improve yield. The above mention traits should be given due emphasis for future okra genetic improvement because they possess high genetic variance, heritability coupled with high genetic correlation among themselves which may yield high genetic advance under proper selection pressure in a breeding programme.

\section{References}

Akhinyele, B.O., and Osekita, O.S. (2006). Correlation and path coefficient analysis of seed yield attributes in Okra [Ablemoschus esculentus (L.) Moench]. African Journal of Biotechnology, 5(14) pp.1330-1336.

Al-Jibouri, H.A., Miller, P.A., Robinson, H. F. (1958): Genetic and environmental variances and covariance in upland cotton cross of interspecific origin. Agron. J., 50: 633-37.

Burton, G.W., and Devane, E.M. (1953). Estimation of heritability in tall fescue (Festica arundinaceae) fromreplicated clonal material. Agron. J.,45:478-481.

Devi, N.D., and Mariappan, S. (2013): Genetic variability, heritability and genetic advance for yield and its components snake gourd (Trichosanthes anguina L.). African J. Agric. Res., 26: 3857-3859.

Dewey, D., and Lu, K. H. (1959). A correlation and path coefficient analysis in crested wheat grass seed production. Journal of Agronomy, 54: 515-518.

Hanson, C.H., Robinson, H. G. and Comstock, R. E. 1956. Biometrical studies of yield in segregating population of Korean. Korean Agron. J. 48: 268-277.

Johnson, H.W., Robinson, H.F., Comstock, R.E. (1955): Estimation of Genetic variability and environmental variability in soybean. J. Agron., 47:314-318.

Kumar P., and Kumar R. (2014). Variability, heritability and character association in okra [Abelmoschus esculentus (L.) Moench]. Asian Journal of Biological Sciences 9 (1): 9-13.

Kumar, S., and Reddy, M.T. (2016).Correlation and path coefficient analysis for yield and its components in okra (Abelmoschus esculentus (L.) Moench). STC agriculture and natural resources, 2(6):01-12.

Mehta, D.R.; Dhaduk, L.K. and Patel, K. D. (2006). Genetic variability correlation and path analysis studies in Okra [Ablemoschus esculentus (L.) Moench]. Agric. Sci. Digest, 26 (2): $15-18$.

Pal, M.K.; Singh, B.; Kumar, R. and Singh, S.K. (2010). Genetic variability heritability and genetic advance in Okra (Abelmoschus esculentusL. Moench). Environment and Ecology., 28 (1A): 469-471. 
Reddy, M.T., Haribabu, K., Ganesh, M. and Beguml, H., Reddy, R.S. and Babu, J.D. (2012). Genetic analysis for yield and its components in okra (Abelmoschus esculentus (L.) Moench). Songklanakarin Journal of Science and Technology, 34(2); 133141.

Saifullah, M., and Rabbani, M. G. (2009). Evaluation and characterization of Okra [Ablemoschus esculentus (L.) Moench] Genotypes. SAARC. J. Agri. 7 (1): 92-99.

Singh, B., and Goswami, A. (2014). Correlation and path coefficient analysis in okra (Abelmoschus esculentus). Indian Journal of
Agricultural Sciences 84(10): 12621266.

Singh, A.K., and Singh, N. (2007). Studies on genetic variability and heritability in balsam (Impaties balsamina). J. Ornamental Hort., 10:128-130.

Singh, B., Pal, A. K. and Singh, S. (2006). Genetic variability and correlation analysis in okra (Abelmoschus esculentus (L.) Moench). Indian Journal of Horticulture, 63(3):281285.

Solankey, S.S., and Singh, A.K. (2009). Path analysis in okra [Abelmoschus esculentus (L.) Moench.]. Asian Science, 4(1 \& 2): 26-31.

\section{How to cite this article:}

Amba Kumari, Vijay Kumar Singh, Manju Kumari and Anand Kumar. 2019. Genetic Variability, Correlation and Path coefficient analysis for Yield and Quality traits in Okra [Abelmoschus esculentus (L.) Moench]. Int.J.Curr.Microbiol.App.Sci. 8(06): 918-926. doi: https://doi.org/10.20546/ijcmas.2019.806.110 